\title{
ERRATA EM: Revista Brasileira de Educação Médica, volume 42, número 3, Julho-Setembro 2019
}

\author{
ERRATUM IN: Brazilian Journal of Medical \\ Education, volume 42, issue 3, July-September \\ 2019
}

No artigo "Cuidados Paliativos: Importância do Tema para Discentes de Graduação em Medicina", com número de DOI: 10.1590/1981-52712015v42n3rb20170105.r1, publicado no periódico Revista Brasileira de Educação Médica, 42(3):78-86, na página 78:

Onde se lia:

"Tathiane da Silva Lucena"

Leia-se:

"Thatiane Silva de Lucena" 